\title{
Analyzing factors that influence the folk use and phytonomy of 18
} medicinal plants in Navarra

\author{
Silvia Akerreta*1, Rita Yolanda Cavero ${ }^{1}$, Víctor López ${ }^{2}$ and \\ María Isabel Calvo ${ }^{2}$
}

Address: ${ }^{1}$ Departamento de Biología Vegetal (Sección Botánica). Universidad de Navarra. C/Irunlarrea s/n, Pamplona. 31080. Navarra. Spain and ${ }^{2}$ Departamento de Farmacia y Tecnología Farmacéutica (Sección Farmacognosia). Universidad de Navarra. C/Irunlarrea s/n, Pamplona. 31080. Navarra. Spain

Email: Silvia Akerreta* - saquerr@alumni.unav.es; Rita Yolanda Cavero - rcavero@unav.es; Víctor López - vlopezra@alumni.unav.es; María Isabel Calvo - mcalvo@unav.es

* Corresponding author

Published: 13 April 2007

Journal of Ethnobiology and Ethnomedicine 2007, 3:16 doi:10.1 I86/1746-4269-3-16

This article is available from: http://www.ethnobiomed.com/content/3/1/16

(C) 2007 Akerreta et al; licensee BioMed Central Ltd.

This is an Open Access article distributed under the terms of the Creative Commons Attribution License (http://creativecommons.org/licenses/by/2.0), which permits unrestricted use, distribution, and reproduction in any medium, provided the original work is properly cited.

\begin{abstract}
Background: This article analyzes whether the distribution or area of use of 18 medicinal plants is influenced by ecological and cultural factors which might account for their traditional use and/or phytonymy in Navarra.

This discussion may be helpful for comparative studies, touching as it does on other ethnopharmacological issues: a) which cultural and ecological factors affect the selection of medicinal plants; b) substitutions of medicinal plants in popular medicine; c) the relation between local nomenclature and uses. To analyze these questions, this paper presents an example of a species used for digestive disorders (tea and camomile: Jasonia glutinosa, J. tuberosa, Sideritis hyssopifolia, Bidens aurea, Chamaemelum nobile, Santolina chamaecyparissus...), high blood pressure (Rhamnus alaternus, Olea europaea...) or skin diseases (Hylotelephium maximum, H. telephium, Anagallis arvensis, A. foemina).

Methods: Fieldwork began on January 2004 and continued until December 2006. During that time we interviewed 505 informants in 218 locations in Navarra. Information was collected using semi-structured ethnobotanical interviews, and we subsequently made maps using Arc-View 8.0 program to determine the area of use of each taxon. Each map was then compared with the bioclimatic and linguistic map of Navarra, using the soil and ethnographic data for the region, and with other ethnobotanical and ethnopharmacological studies carried out in Europe.

Results: The results clearly show that ecological and cultural factors influence the selection of medicinal plants in this region. Climate and substrate are the most important ecological factors that influence the distribution and abundance of plants, which are the biological factors that affect medicinal plant selection.

Conclusion: The study of edaphological and climatological factors, on the one hand, and culture, on the other, can help us to understand why a plant is replaced by another one for the same purposes, either in the same or in a different area. In many cases, the cultural factor means that the use of a species is more widespread than its ecological distribution. This may also explain the presence of synonyms and polysemies which are useful for discussing ethnopharmacological data.
\end{abstract}




\section{Background}

Ethnobotany is the science that describes the relationship between humans and plants but the factors that influence that relationship are not well defined. The interdisciplinary approach is well known in ethnobotany [1-3] and can help us to understand what factors may interact and have a decisive influence on the selection of plants used by humans, and on the origin of synonyms (different names to refer to one plant taxon) $[4,5]$ and polysemies (use of one name to refer to different plant taxa) $[4,5]$ in the same area.

Many abiotic factors affect the distribution and abundance of plants, including climate, substrate, geomorphology, altitude and solar exposure. As suggested by Johns et al. [6], if a species is more abundant in one area, it will most probably be used to treat a common problem in that community. But is abundance the only factor, or are other issues involved, such as cultural influences or fashions?.

After a preliminary sampling of the study area, a bioclimatological and edaphological study of a specific location can provide an idea, a priori, of the most common plants that can be found there and can help to provide an overview of the potential distribution of use (meaning the same use in a different place) of the common species. Another decisive factor in the distribution of use of a species or its selection as medicinal is the history and culture of the local population, which is also affected by the degree of isolation from other cultures.

When we carried out part of the ethnobotanical study of Navarra [7], we noted striking distributions of use or phytonymies, or even possible substitutions between species according to the area in question. In the present paper, we analyze the possible influence of environmental and cutural factors in the variations and/or substitutions of 18 species, given the great diversity of the region and its exemplary nature as regards biotic and abiotic factors.

The objectives of this study were therefore:

\section{Objectives}

(1) To demonstrate whether ecological and cultural factors have a decisive influence on the extent of use or selection and/or phytonymy of 18 medicinal plants in Navarra.

(2) To analyze and discuss which causes or factors lead to the replacement of medicinal plants in traditional medicine.

(3) To analyze the relationship between phytonymy and plant use.

\section{Study area}

Navarra is a region $\left(10.421 \mathrm{~km}^{2}\right)$ in the northern Iberian Peninsula (Fig. 1) in the western sector of the Pyrenees Mountains. Starting at the limestone Pyrenean foothills reaching heights of 2,428 meters which tower over steepsided valleys composed of flysch [8], the landscape then softens into a geomorphology based on marls and limestone marls. In the middle zone, characterized by its transitional nature, marls and limestone blend with sandstones, gradually yielding to gypsum, gravel, sand and mud which predominate in broad, windswept plains that have been eroded over the course of time.

According to López et al. [[9]; p90], Navarra includes two macro-bioclimates, Temperate and Mediterranean, separated by a dividing chain of mountains (Fig. 1).

The oceanic temperate bioclimate appears in the northern part of the territory, and is characterized by mild temperatures and high precipitation throughout the year. More to the south, as precipitation decreases, the oceanic temperate bioclimate changes to the sub-Mediterranean variant and finally to the seasonal-rainfall Mediterranean bioclimate, characterized by seasonal drought (favoring species that are specifically Mediterranean). The latter bioclimate occupies most of the territory to the south, although there is also a small island of xeric Mediterranean in an area that is now a Biosphere Reserve due to its ecological importance (Bardenas Reales) [10]. Owing to its geological, geomorphological and bioclimatic variability, it has a rich flora (2650 vascular plants) [11].

All these climatic factors, along with the geomorphologic and edaphological ones, which change sharply in a relatively small area, provide a great diversity of plant communities, such as the forests of elm trees, both basophilic and acidophilic (one of the best conserved in Europe is the Irati forest), the groves of Quercus robur L. oak and Q. humilis Miller, as well as holm oak, evergreen oak, gall oak, and Pyrenean pastures rich in the Alpine and subAlpine plant series, among others [12,13].

The area was inhabited by the Basques until the arrival of the Romans. It was later populated by the Visigoths. Nowadays, only $10 \%$ of the population of Navarra speaks "Euskera", the language of the Basque ethnic group, though the percentage of Euskera speakers was higher in recent times (s. XVIII-XIX) [14], which influences some aspects of present-day culture, including ethnobotany. Nonetheless, in the north-west there is a greater influence of the Basque culture and language, which has a direct influence on the use and names of the plants (Fig. 2). 


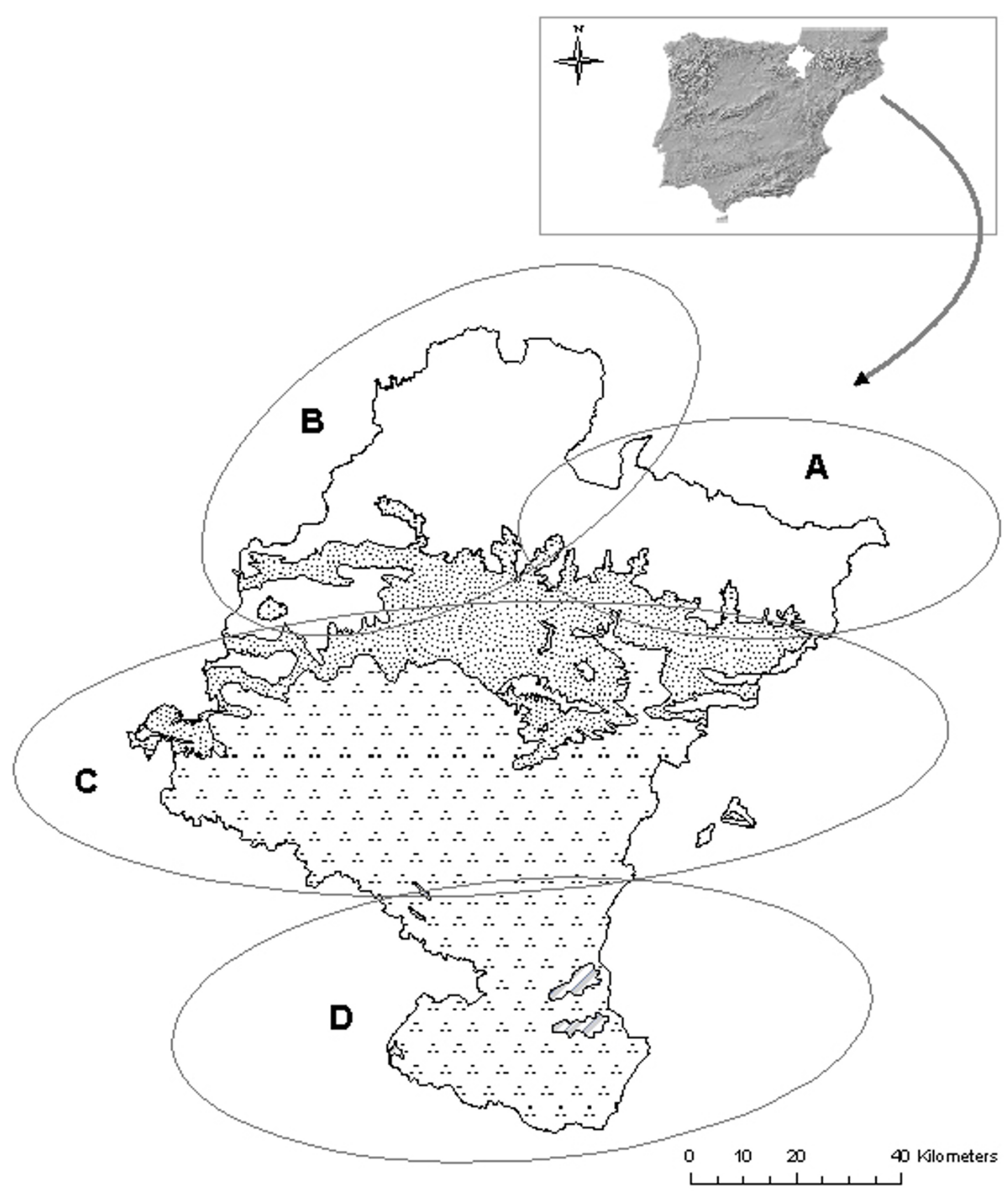

\section{Figure I}

Location of Navarra, bioclimates and principal biogeographical regions. Bioclimates. Blank area: Temperate oceanic. Randomdotted area: Temperate oceanic sub-mediterranean. Aggregately dottedarea: Mediterranean pluviseasonal. Striped area: Mediterranean xeric. Biogeographical areas of Navarra. A-Pyrenees area. B-Humid area of northwest. C-The Central zone. D-The Ribera. 


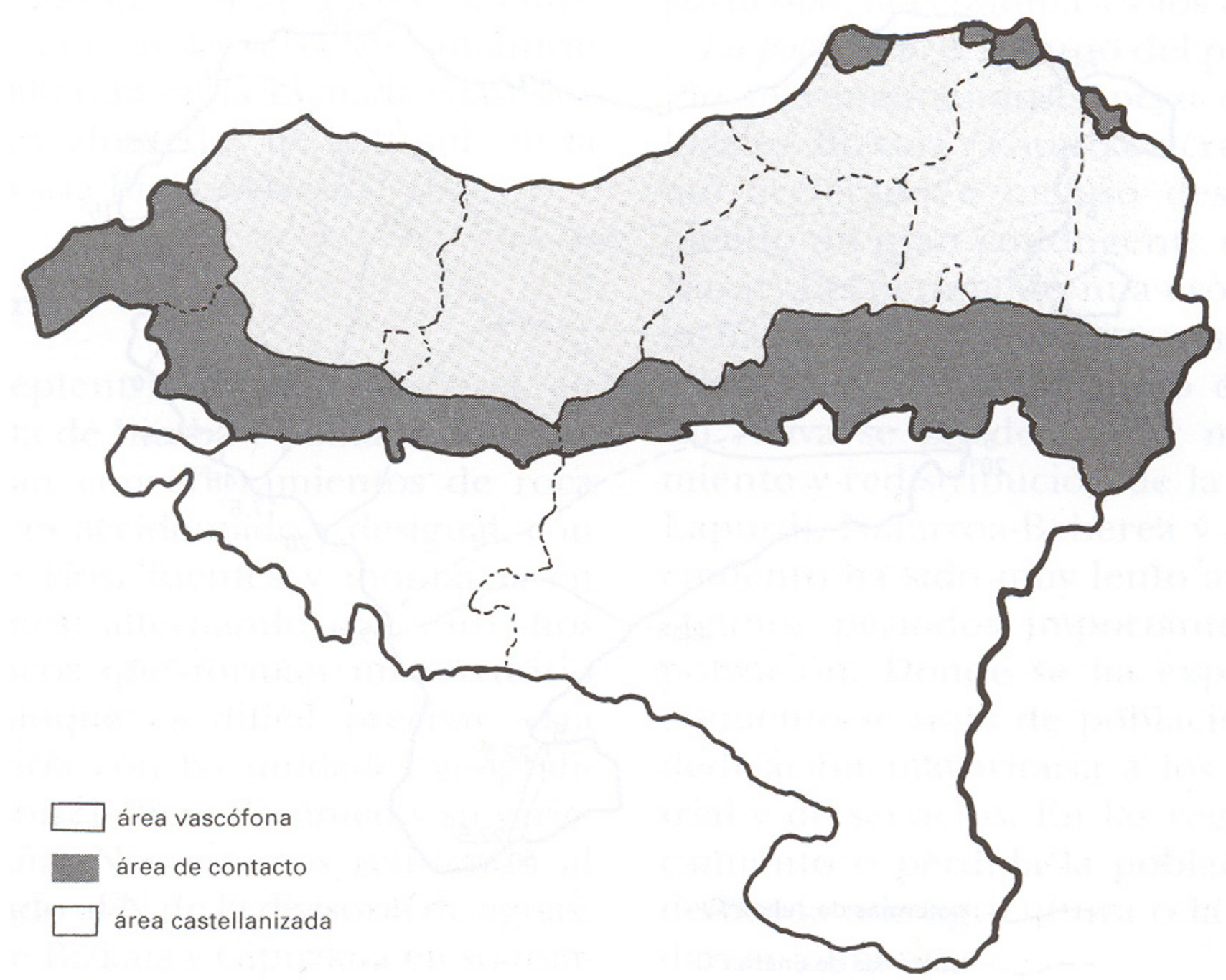

Figure 2

Linguistics areas of Vasconia (From "Atlas Etnografico de Vasconia. Medicina popular en Vasconia" [14]). Blank area: Spanishspeaking area. Light grey: Contact area. Dark grey: Basque-speaking area.

\section{Material and methods}

Field and laboratory work began on January 2004 and lasted until December 2006. During that time we interviewed 505 informants in 218 locations in Navarra (Fig. 1). Information was collected using semi-structured ethnobotanical interviews as described by Martin [14]. Those interviews were always carried out spontaneously with people born or having lived most of their lives in the region studied.

Of those interviewed, $54.3 \%$ were women. The ages of the interviewees ranged from 22 to 100 year, the age group from 71 to 80 years representing the mean. When possible, the conversations were recorded.

In the field work we noted for each species the local name, place and collection method, drying and preservation system, parts or organs used and method of preparation, dosage and administration. The species were collected with the interviewee in situ and then identified in the laboratory using keys for botanical determination, labeled and included in the PAMP Herbarium at the School of Science. The bibliography used for taxonomic determination was Flora Iberica [16], and for unpublished families, we used 
Flora of the Basque Country [17]. The local names were transcribed and processed following the methodology of phytonymy [18].

From the preliminary ethnobotanical study, 18 species were selected for the present study, on the following grounds:

1-species used for 3 of the commonest disorders in Navarra [7]: gastrointestinal, circulatory (hypertension) and dermatological complaints.

2-From these, we selected those species which, in addition to being mentioned by more than three informants, were found to have: a) noteworthy distributions or areas of use (densely within one area, or across the whole region), and/or clear variations in phytonymy according to area.

For each of these species we drew up a map of the distribution of use and/or phytonymy using the program ArcView 8.0, taking the coordinates of the places where the species were mentioned by the informants. These maps were compared with the bioclimatic [9] and linguistic maps of Navarra (Fig. 2) [13]; edaphological data about the region [8]; ethnographic research carried out in the study area, such as that by Lacoizqueta [19], Barriola [20], Erkoreka [21] or Etniker-Euskalerria [14], among others cited in the text; ethnobotanical studies performed in different regions of the Iberian Peninsula, such as Bonet et al. [22-24], Agelet and Vallès [25-27], Fajardo et al. [28], González-Tejero et al. [29], Lastra and Bachiller [30], Martínez et al. [31], Vázquez et al. [32], Pardo de Santayana et al. [33], Villar et al. [34], Tardío et al. [35], or Parada et al. [36], as well as other ethnobotanical and pharmaceutical studies performed in Europe and in the rest of the world (cited in text).

\section{Results and discussion}

The selected species used for improving the digestion, high blood pressure and for skin disorders are presented in Table 1, 2 and 3. All the species collected are still used for those purposes.

Teas and chamomiles for digestive remedies:

Among those used for digestive problems, there are two groups of species: those with names derived from "té" (tea) and those from "manzanilla" or "kamamila" (chamomile). Jasonia glutinosa or "té de roca" (rock tea) is the species called tea which is most commonly used in Navarra (see Fig. 3). It is mostly used by inhabitants close to calcareous mountain ranges, as is the case in other studies where that species has been cited [33-35,37-40]. That is because rock tea has an exclusive habitat in cracks, rock ledges and fissures that receive plenty of sunlight, thus its area of use is first influenced by the substrate. However, people that live in communities of the south of Navarra far from the areas where it grows commented that it should be harvested in the mountains, and that in the past, it could be purchased in the villages. We therefore believe that the cultural factor, rather than the environmental factor, determines its distribution. Previous studies have shown that its chemical composition includes many oxygenated terpenes and sesquiterpene derivatives [41], the latter of which have anti-inflammatory effects in vitro [42]. There are also a considerable amount of saponins, both steroidal and triterpenic [33], as well as tannins [43], which could explain its use, albeit a limited one, as an anti-diarrheic. Because of these chemical properties, or because the influence of culture or fashion, the use of this species has spread beyond its natural boundaries (Table $4)$.

Another species called and consumed as té (tea) is Jasonia tuberosa, which is used in the south, in places where the use of Jasonia glutinosa declines, which indicates that the use of one replaces that of the other. It only grows in flat locations with a marl substrate and Mediterranean environment $[8,17]$. Thus, the substrate and climate are decisive for the distribution of use of that species and help to explain this polysemy and substitution: the same use and same name indicate that if Jasonia glutinosa is not present in the area, but a similar one, in this case Jasonia tuberosa, is available, then it is replaced by the latter. When an informant in this area goes north to obtain Jasonia glutinosa, he or she considers this species to be of top quality, while Jasonia tuberosa is of secondary quality and should only be used as a substitute. The aerial parts of this European endemism, which is only found in the Iberian Peninsula and southern France [39], are also used as a digestive and to clear the mind. According to Gil Pinilla [44], its main component, camphor, is used to treat gastrointestinal disorders, and has spasmolytic, anesthesic, analgesic, antiemetic, antiseptic and carminative properties.

Sideritis hyssopifolia L. ssp. guillonii, also called "té de roca" (rock tea), is considered endemic to the northwest Mediterranean-orophyte $[45,46]$. Several species of Sideritis are used in different European regions [24,25,34,35,37,4752]. This polymorphic taxon appears, as its colloquial name indicates, in rocky outcrops or crevices in high crags, often in the same habitat as Jasonia glutinosa; however, in Navarra the only population of Sideritis hyssopifolia has been mentioned in an isolated valley of glacial origin, near the mountain peaks. In this isolated place it is the cultural factor which has kept this species in use into our own day; this is also the case in the western mountains, where the cultural factor is the deciding one, though in this case it favors the exclusive use of Jasonia glutinosa, as 
Table I: Selected species used for gastrointestinal disorders and called "té" (tea) or "manzanilla/kamamila" (camomile) in Navarra

\begin{tabular}{|c|c|c|c|c|c|c|c|c|}
\hline & \multirow[t]{2}{*}{ Species } & \multirow[t]{2}{*}{ Habitat } & \multicolumn{2}{|c|}{ Local name } & \multirow[t]{2}{*}{ PUa } & \multirow[t]{2}{*}{$\mathbf{P b}^{\mathbf{b}}$} & \multirow[t]{2}{*}{ Popular use } & \multirow[t]{2}{*}{$\mathbf{C c}$} \\
\hline & & & Spanish & Basque & & & & \\
\hline \multicolumn{9}{|c|}{ Medicinal plants named "té" } \\
\hline & \multicolumn{8}{|l|}{ ASTERACEAE } \\
\hline I & $\begin{array}{l}\text { Bidens aurea (Aiton) Sherff (PAMP } \\
\text { 19668-19675) }\end{array}$ & Cultivated & $\begin{array}{l}\text { Té Americano, } \\
\text { té del fraile }\end{array}$ & & AP & I & Stomach ache. & 8 \\
\hline 2 & $\begin{array}{l}\text { Jasonia glutinosa (L.) DC (PAMP I8642, } \\
\text { |8768-|877I) }\end{array}$ & $\begin{array}{l}\text { Cracks, rock ledges and } \\
\text { fissures }\end{array}$ & $\begin{array}{l}\text { Té de roca, té } \\
\text { de peña }\end{array}$ & & AP & 1 & $\begin{array}{l}\text { Digestive, stomach ache, to purify } \\
\text { the blood and Raise the spirits, } \\
\text { clear the mind. }\end{array}$ & 113 \\
\hline \multirow[t]{2}{*}{3} & $\begin{array}{l}\text { Jasonia tuberosa (L.) DC (PAMP I8772, } \\
\text { |8773) }\end{array}$ & Marly substrate & Té & & AP & 1 & $\begin{array}{l}\text { Stomach ache and to Raise the } \\
\text { spirits. }\end{array}$ & 34 \\
\hline & LAMIACEAE & & & & & & & \\
\hline 4 & $\begin{array}{l}\text { Sideritis hyssopifolia L. subsp. guillonii } \\
\text { (Timb.-Lagr.) Rouy (PAMP I8698, I8699, } \\
\text { |8750, I875।) }\end{array}$ & $\begin{array}{l}\text { Cracks, rock ledges and } \\
\text { fissures }\end{array}$ & Té de roca & & AP & I & $\begin{array}{l}\text { Digestive, stomach ache and to } \\
\text { bloating. }\end{array}$ & 5 \\
\hline \multicolumn{9}{|c|}{ Medicinal plants named "kamamila or manzanilla" } \\
\hline & \multicolumn{8}{|c|}{ ASTERACEAE } \\
\hline I & Anthemis arvensis L. (PAMP I8758) & RUDERAL & Manzanilla basta & & FT & 1 & $\begin{array}{l}\text { Digestive, stomach acidity, gut } \\
\text { pain. }\end{array}$ & 8 \\
\hline 2 & $\begin{array}{l}\text { Chamaemelum nobile (L.) All. (PAMP } \\
\text { I8640, I864I, I8759-I8763) }\end{array}$ & Temperatura pasture & $\begin{array}{l}\text { Manzanilla, } \\
\text { manzanilla fina, } \\
\text { manzanilla de } \\
\text { monte, } \\
\text { manzanilla de } \\
\text { Urbasa, Aralar }\end{array}$ & Kamamila & FT & 1 & $\begin{array}{l}\text { Digestive, gut pain, for bad mood, } \\
\text { stomach acidity, laxative, anti- } \\
\text { diarrhoeal, tranquillizer. }\end{array}$ & 119 \\
\hline 3 & $\begin{array}{l}\text { Helichrysum stoechas (L.) Moench } \\
\text { subsp.stoechas (PAMP 18766, I8767) }\end{array}$ & Dry or stony pastures & $\begin{array}{l}\text { Manzanilla, } \\
\text { manzanilla dulce, } \\
\text { manzanilla fina }\end{array}$ & & FT & 1 & Digestive & 15 \\
\hline 4 & Matricaria recutita L. (PAMP I8764) & Cultivated & Manzanilla & & FT & 1 & Stomach ache & 5 \\
\hline \multirow[t]{2}{*}{5} & $\begin{array}{l}\text { Santolina chamaecyparissus L. subsp. } \\
\text { squarrosa (DC) Nyman (PAMP I8643- } \\
\text { 18649, I8749, 18775-18782) }\end{array}$ & $\begin{array}{l}\text { Open scrubland and dry } \\
\text { or stones pastures }\end{array}$ & $\begin{array}{l}\text { Manzanilla, } \\
\text { manzanilla de } \\
\text { monte, } \\
\text { manzanilla basta, } \\
\text { manzanilla de } \\
\text { burro, hierba } \\
\text { para el mal de } \\
\text { las gallinas }\end{array}$ & & FT & 1 & $\begin{array}{l}\text { Digestive, headache, stomach } \\
\text { ache, belly pain, stomach } \\
\text { problems, to clean the blood } \\
\text { (depurative), tranquillizer nuisance } \\
\text { and veterinary (digestive for } \\
\text { sheeps). }\end{array}$ & 169 \\
\hline & & & & & & $\mathrm{HB}(\mathrm{D})$ & Woman hygiene. & \\
\hline \multirow[t]{3}{*}{6} & $\begin{array}{l}\text { Tanacetum parthenium (L.) Sch. Bip. } \\
\text { (PAMP } 18650,18783,18784 \text { ) }\end{array}$ & Cultivated & $\begin{array}{l}\text { Manzanilla de } \\
\text { huerta, } \\
\text { manzanilla } \\
\text { amarga }\end{array}$ & San Juan Lorek & FT & 1 & $\begin{array}{l}\text { Digestive, stomach ache, bile } \\
\text { problems. }\end{array}$ & 8 \\
\hline & & & & & & $\mathrm{HB}(\mathrm{D})$ & Woman hygiene. & \\
\hline & & & & & & $\mathrm{R}$ & $\begin{array}{l}\text { To protect the country house } \\
\text { from storms and misfortune. }\end{array}$ & 10 \\
\hline
\end{tabular}

a) PU: part used; AP: aerial part; FT: floral top

b) D: decoction; HB: hip bath; I: infusion; R: rite; V: veterinary use.

c) C: Citations.

we saw above. This means that Sideritis hysopifolia is less widely used than its geographical distribution might indicate (Table 4). Since there are different species of Sideritis, scientific research on that genus is quite diverse as well. However, the chemical composition in broad outline of $S$.

Table 2: Selected species used for circulatory disorders (high blood preassure).

\begin{tabular}{|c|c|c|c|c|c|c|c|c|}
\hline & \multirow[t]{2}{*}{ Species } & \multirow[t]{2}{*}{ Habitat } & \multicolumn{2}{|c|}{ Local name } & \multirow[t]{2}{*}{ PUa } & \multirow[t]{2}{*}{$\mathbf{P b}$} & \multirow[t]{2}{*}{ Popular use } & \multirow[t]{2}{*}{ Citations } \\
\hline & & & Spanish & Basque & & & & \\
\hline & OLEACEAE & & & & & & & \\
\hline \multirow[t]{2}{*}{ I } & Olea europaea L. subsp. europaea & Cultivated & Olivo & & L & $\mathrm{D}$ & High blood preassure & 33 \\
\hline & RHAMNACEAE & & & & & & & \\
\hline \multirow[t]{2}{*}{2} & Rhamnus alaternus L. (PAMP I9664-19667) & Woods and scrublands & & Karraskila & B & $\mathrm{D}$ & High blood preassure & 15 \\
\hline & URTICACEAE & & & & & & & \\
\hline 3 & Urtica dioica L. (PAMP 19652-1966I) & Ruderal & Ortiga & Atsun, osina & AP & 1 & High blood preassure & 18 \\
\hline 4 & Urtica urens L. (PAMP 19662) & Ruderal & Ortiga & Atsun, osina & AP & 1 & High blood preassure & \\
\hline
\end{tabular}

a) AP: aerial part; B: branch; L: leaf.

b) D: decoction; I: infusion. 
Table 3: Selected species used for skin disorders.

\begin{tabular}{|c|c|c|c|c|c|c|c|c|}
\hline & \multirow[t]{2}{*}{ Species } & \multirow[t]{2}{*}{ Habitat } & \multicolumn{2}{|c|}{ Local name } & \multirow[t]{2}{*}{ PUa } & \multirow[t]{2}{*}{$\mathbf{P b}$} & \multirow[t]{2}{*}{ Popular use } & \multirow[t]{2}{*}{ Citations } \\
\hline & & & Spanish & Basque & & & & \\
\hline & CRASSULACEAE & & & & & & & \\
\hline I & $\begin{array}{l}\text { Hylotelephium maximum (L.) Holub. (PAMP } \\
\text { 19676, 19678-19684) }\end{array}$ & Cultivated & Curalotodo & & $\mathrm{L}$ & DA & Skin diseases:wounds, spots... & 23 \\
\hline \multirow[t]{2}{*}{2} & $\begin{array}{l}\text { Hylotelephium telephium (L.) H. Ohba (PAMP } \\
\text { 19677) }\end{array}$ & Cultivated & Curalotodo & & $\mathrm{L}$ & DA & Skin diseases:wounds, spots... & 1 \\
\hline & PRIMULACEAE & & & & & & & \\
\hline 3 & Anagallis arvensis L. (PAMP 19647-19649) & Ruderal & & Pasmobelarra & AP & $\mathrm{P}, \mathrm{O}$ & Skin diseases: infected wounds ("bixiko") & 15 \\
\hline \multirow[t]{2}{*}{4} & Anagallis foemina Mill. (PAMP 19650) & Ruderal & & Pasmobelarra & AP & $\mathrm{P}, \mathrm{O}$ & Skin diseases: infected wounds ("bixiko") & 3 \\
\hline & LILIACEAE & & & & & & & \\
\hline 5 & Allium cepa L. & Cultivated & Cebolla & Tipula & $\mathrm{L}$ & O, DA & $\begin{array}{l}\text { Skin diseases: infected wounds ("bixiko", } \\
\text { "panadizo"..) }\end{array}$ & 82 \\
\hline
\end{tabular}

a) AP: aerial part; L: leaf

b) DA: direct application; P: poultice; O: ointment

hyssopifolia is known: Rodriguez Lyon et al. [53] have shown that its digestive properties are due to flavonoids.

Bidens aurea is a tea which is known today only in a few places in the south of Navarra. A native of Central America [54], it was brought back by a missionary friar many decades ago, according to our interview data. It used to be grown, but now occurs as an invader in irrigation channels, as Pardo de Santayana \& Morales state for other regions within the Iberian peninsula [33]. Its cultivation and naturalization, favored by environmental factors, are exclusively explained by cultural factors supported by the chemical properties of the plant $[33,55]$. As it is not autochthonous and has to be cultivated, its distribution of use is greater than its ecological distribution.

None of the four species known as tea in Navarra have a monograph in WHO [56], ESCOP [57] or the E Commission [58]. This is most probably due to the lack of research on their chemical composition and, according to MuñozCenteno [59], since these medicinal species are only used in the Iberian Peninsula, they are not very well analyzed, although Fernández [60] states that the fact that they are still used confirms their effectiveness.

Other herbs used to treat digestive disorders include many species known as chamomile (Fig. 4 and Fig. 5). All these species belong to the Asteraceae family and have similar indications (Table 1). Popularly in Navarra there has always been some confusion between the stomach and the intestines, since everything in the abdomen is considered to be the same thing, including the abdominal viscera. As a result, stomach or intestinal pains, or even specific female pains (e.g., menstrual pain), sometimes have similar remedies [14].

Santolina chamaecyparissus subsp. squarrosa was found to be the most commonly used plant called "manzanilla" (chamomile), which is at variance with the assertion by
García Bona [61] that it was "rarely" used in Navarra. It is characteristic of Mediterranean climates with a basophilic soil, and is distributed throughout the Mediterranean bioclimate and Temperate Oceanic of sub-Mediterranean variant and, in this case, on sunny slopes, as is the case in other regions with similar bioclimatic characteristics [22,24,34,40,62-64]. As a result of its ecological distribution, it is more frequent in the central zone of Navarra. It is interesting that although it is the most often mentioned chamomile, it is also the one which has pejorative names when its use overlaps with Chamaemelum nobile or Helichrysum stoechas, a phenomenon which points to the fact that it is often replaced by these species.

Chamaemelum nobile (L.) All. follows Santolina chamaecyparissus subsp. squarrosa in terms of use. However, this use is distributed across marl-based pastures throughout the Temperate oceanic climate, that is, in northern Navarra. The use of this chamomile has also been noted in other ethnobotanical studies in areas that have a similar temperate climate to northern Navarra [65-69]. However, it is also used in the Mediterranean region by locals who go to the northern mountains for this special chamomile. Interestingly, these people that go to the northern areas to gather Chamaemelum nobile, call Santolina chamaecyparissus by the pejorative name "manzanilla basta" (rough or donkey chamomile) o "hierba para el mal de las gallinas" (grass for hen sickness), indicating that S. chamaecyparissus is a substitute for $C$. nobile. Its chemical composition and pharmacological activity are very similar to Matricaria recutita [70]. The apigenin derivatives in its chemical composition may be responsible for its spasmolytic activity, which explains its digestive and sedative properties [71]. These mean that it is regarded culturally as a first-class chamomile, thereby accounting for the fact that it is used beyond the boundaries of its ecological distribution.

Helichrysum stoechas is used as a chamomile in the South, in the Mediterranean area with poor soils [18]. It has also 


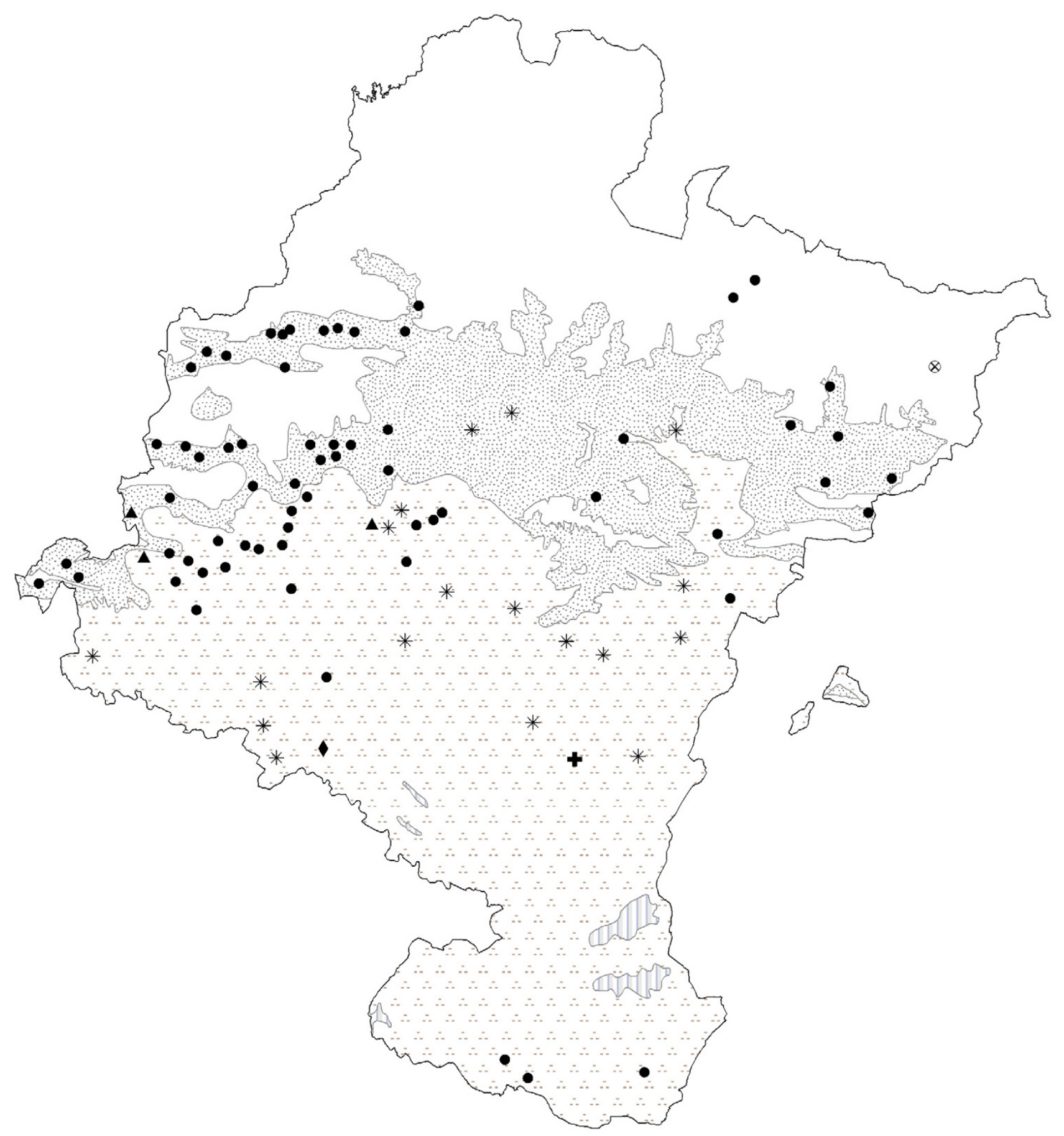

Figure 3

Map of the distribution of use of teas.

- Jasonia glutinosa. * Jasonia tuberosa. A Jasonia glutinosa and/or Jasonia tuberosa. + Jasonia tuberosa and/or Bidens aurea. $\diamond$ Jasonia glutinosa and/or Bidens aurea. $\oplus$ Sideritis hyssopifolia subsp.guillonii.

Bioclimates. Blank area: Temperate oceanic. Random dotted area: Temperate oceanic sub-mediterranean. Aggregately dotted area: Mediterranean pluviseasonal. Striped area: Mediterranean xeric. 
Table 4: Relation between use distribution and ecological distribution ${ }^{\mathrm{a}}$.

\begin{tabular}{lcc}
\hline Species & UD > ED & UD $\pm=$ ED \\
\hline Allium cepa & $\cdot$ \\
Anagallis arvensis-A. foemina & \\
Anthemis arvensis & $\cdot$ \\
Bidens aurea & $\cdot$ \\
Chamaemelum nobile & \\
Helichrysum stoechas & $\cdot$ \\
Hylotelephium maximum-H. telephium & $\cdot$ \\
Jasonia glutinosa & \\
Jasonia tuberosa & $\cdot$ \\
Matricaria recutita & $\cdot$ \\
Olea europaea & \\
Rhamnus alaternus & \\
Santolina chamaecyparissus & \\
Sideritis hyssopifolia & \\
Tanacetum parthenium \\
Urtica dioica-U. urens
\end{tabular}

a) UD: use distribution; ED: ecological distribution.

been cited in other warmer locations in the Iberian Peninsula $[62,63]$ and in Navarra it has almost the same ecological distribution as $S$. chamaecyparissus [17], which are known where they are used as "manzanilla fina" ("fine chamomile") and "manzanilla basta" ("rough chamomile") respectively. The cultural factor, supported by the plant's chemical properties [72,73], was not decisive enough to prevent its distribution of use being smaller than that of $S$. chamaecyparissus (which was favored by environmental factors which make it much more widely available).

Anthemis arvensis L. or "manzanilla basta " (rough chamomile) has been cited in the same humid area as Chamaemelum nobile and, while the latter is harvested in the green pastures in the mountains, A. arvensis appears close to houses and, according to informants, is used for emergencies, when C. nobile is not available. In fact, according to Ladero et al., [62: 184], this species is often used as an adulteration of $C$. nobile and Matricaria recutita. In this case, its wide availability does not mean that it is used more, since it is only used sporadically, and so the pattern proposed by Johns et al. [6] is not followed. In fact, the cultural factor is decisive in this case, because this species is considered to be of second-rate quality, and it is therefore regarded as a mere substitute for $C$. nobile, which has superior chemical properties that make it the plant of choice.

Another species called chamomile is Tanacetum parthenium. In Navarra there is a synonymy for this plant, explained by its two different uses: in the northeast and in the Basque-speaking area, the aerial parts of the plant called "San Juan Lorek" are collected in a bunch and placed on the door of country houses to protect them from "lightning and misfortune". According to Abella [74: 276], this use has also been noted in villages of Vizcaya (Basque Country). On the other hand, it is cultivated to a lesser extent in the orchards of some villages to obtain a infusion until the so called "manzanilla silvestre" (wild chamomile, S. chamaecyparissus subsp. squarrosa) is available in other areas (that is, warmer areas than the Pyrenean villages in question). As it is more widely available, cultural factors mean that it is used as a substitute for the proper chamomile (S. chamaecyparissus) when this is not available or accessible. Its dried aerial flower parts are consumed as a digestive infusion, to wash the eyes and as a hip bath for woman. These indications correspond to its chemical composition [75-78]. Nonetheless, none of these indications have yet been recognized in the monographs written by the WHO [56] or ESCOP [57] on these species.

Lastly, we found Matricaria recutita. It is still used (sometimes cultivated) for medicinal purposes in various areas of the Iberian Peninsula [22,35-38,40,66,68,79,80]. Nonetheless, this plant is in the group of chamomiles used least in the traditional medicine of Navarra. Cultural reasons explain why this allochthonous species is not chosen for cultivation despite the fact that it is the most popular chamomile in the world with properties that are widely described in the bibliography of the subject [8185].

Circulatory disorders: plants use for high blood pressure:

Rhamnus alaternus or karraskila, which grows in woods and scrublands throughout the area $[17,45]$ (Table 2), is 


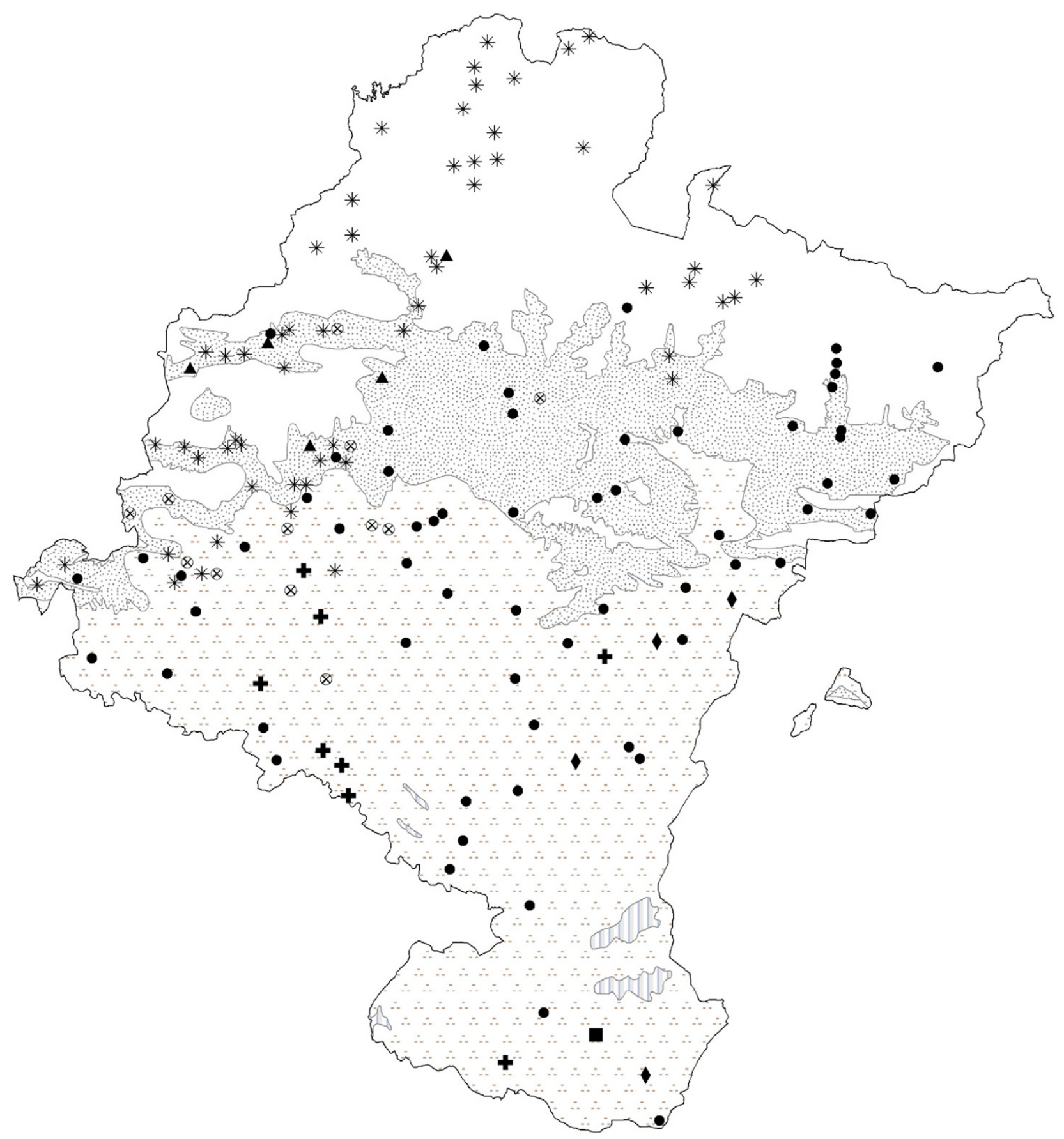

\section{Figure 4}

Map of the distribution of use of camomiles (except Tanacetum parthenium).

Santolina chamaecyparissus subsp. squarrosa. * Chamaemelum nobile. $\oplus$ Chamaemelum nobile. and/or S. chamaecyparissus subsp. squarrosa. $\mathbf{\Delta}$ Chamaemelum nobile and/or Anthemis arvensis. + Santolina chamaecyparissus subsp. squarrosa and/or Helichrysum stoechas. Santolina chamaecyparissus subsp. squarrosa and/or Matricaria recutita. Helichrysum stoechas.

Bioclimates. Blank area: Temperate oceanic. Random dotted area: Temperate oceanic sub-mediterranean. Aggregately dotted area: Mediterranean pluviseasonal. Striped area: Mediterranean xeric. 


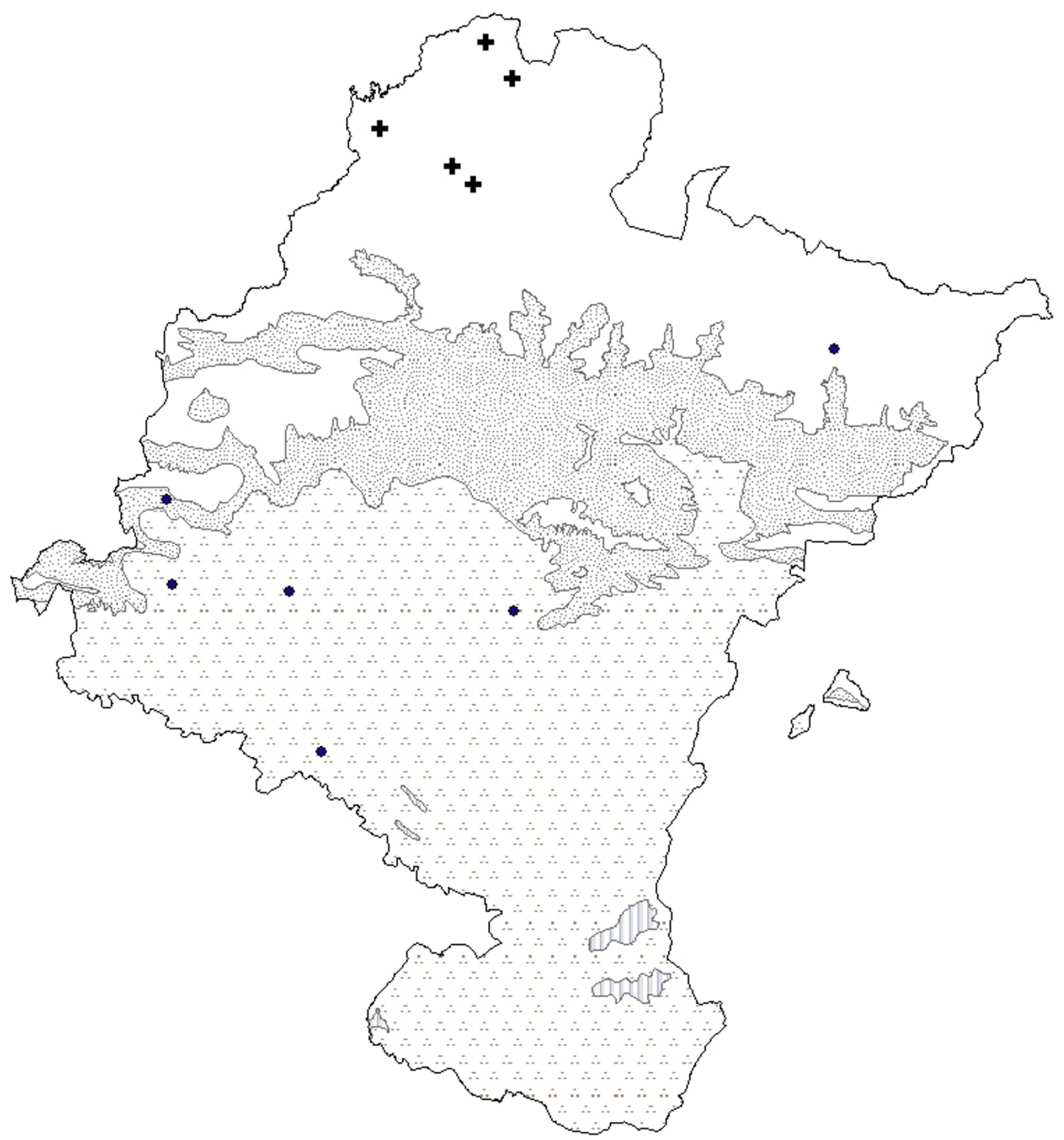

\section{Figure 5}

Map of the distribution of use of Tanacetum parthenium. + Like as "San Juan Lorek". Like as camomile. Bioclimates. Blank area: Temperate oceanic. Random dotted area: Temperate oceanic sub-mediterranean. Aggregately dotted area: Mediterranean pluviseasonal. Striped area: Mediterranean xeric.

more used in the principal Basque-speaking area, as its use depends on cultural as well as on biogeographical factors (Fig. 6). In the south, olive production was adopted a long time ago and the inhabitants learned its medicinal uses from their neighbors to the south. Indeed, such uses have been reported in many surveys carried out in the Iberian Peninsula $[24,35]$ and its leaves have been shown to contain triterpenoids that substantiate its traditional indica- 


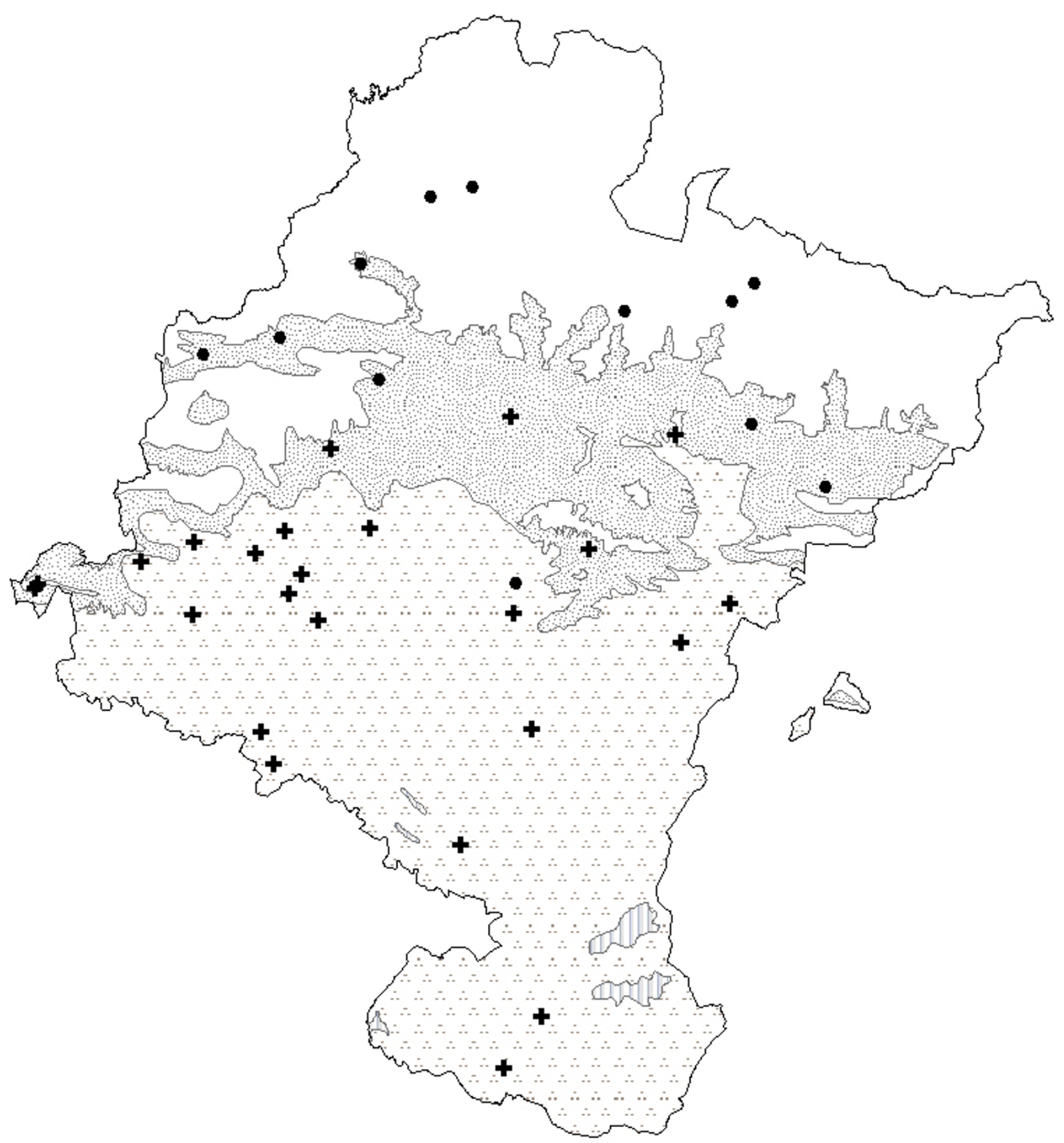

\section{Figure 6}

Map of the distribution of use of hypotensive species (I) (except Urtica dioica). + Olea europea. Rhamnus alaternus. Bioclimates. Blank area: Temperate oceanic. Random dotted area: Temperate oceanic sub-mediterranean. Aggregately dotted area: Mediterranean pluviseasonal. Striped area: Mediterranean xeric.

tions [86]. Another plant in this group, which is more cosmopolitan, is "ortiga", "atsun" (of "asun" nettle, [19]) or "osina". This plant, with its similar common names and morphological characteristics, according to Linares et al. [87], is ruderal [17] and therefore widely available in case of need. The fact that it is not necessary to climb 


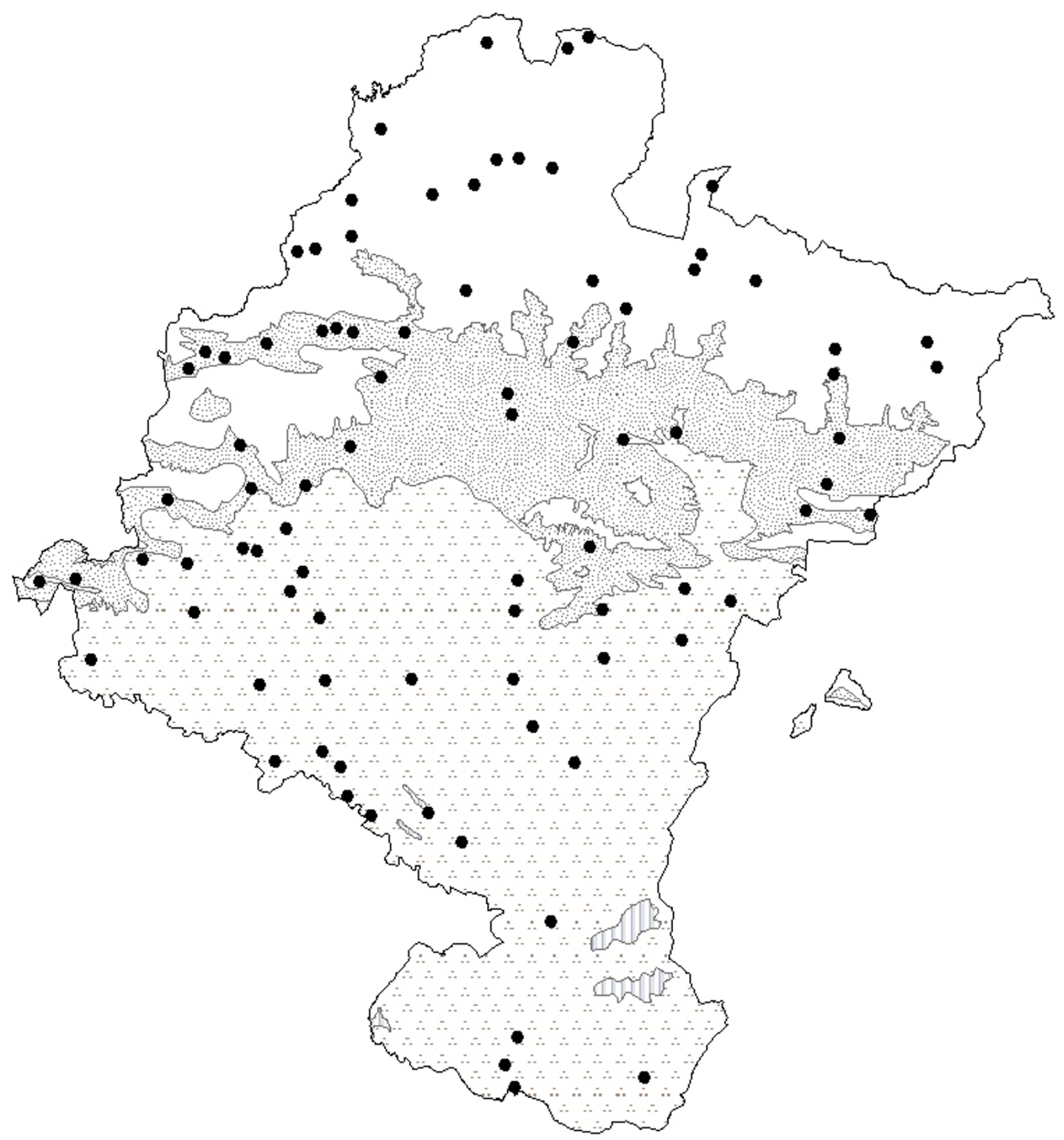

Figure 7

Map of the distribution of use of hypotensive species (2). Urtica dioica. Bioclimates. Blank area: Temperate oceanic. Random dotted area: Temperate oceanic sub-mediterranean. Aggregately dotted area: Mediterranean pluviseasonal. Striped area: Mediterranean xeric.

mountains to obtain it (as is the case with Rhamnus alater$n u s$ ), or to grow it oneself (Olea europaea), accounts for its notable widespread use throughout the region (Fig. 7). Its distribution of use is the largest for plants employed to treat circulatory disorders, and is the same size as its ecological distribution. 


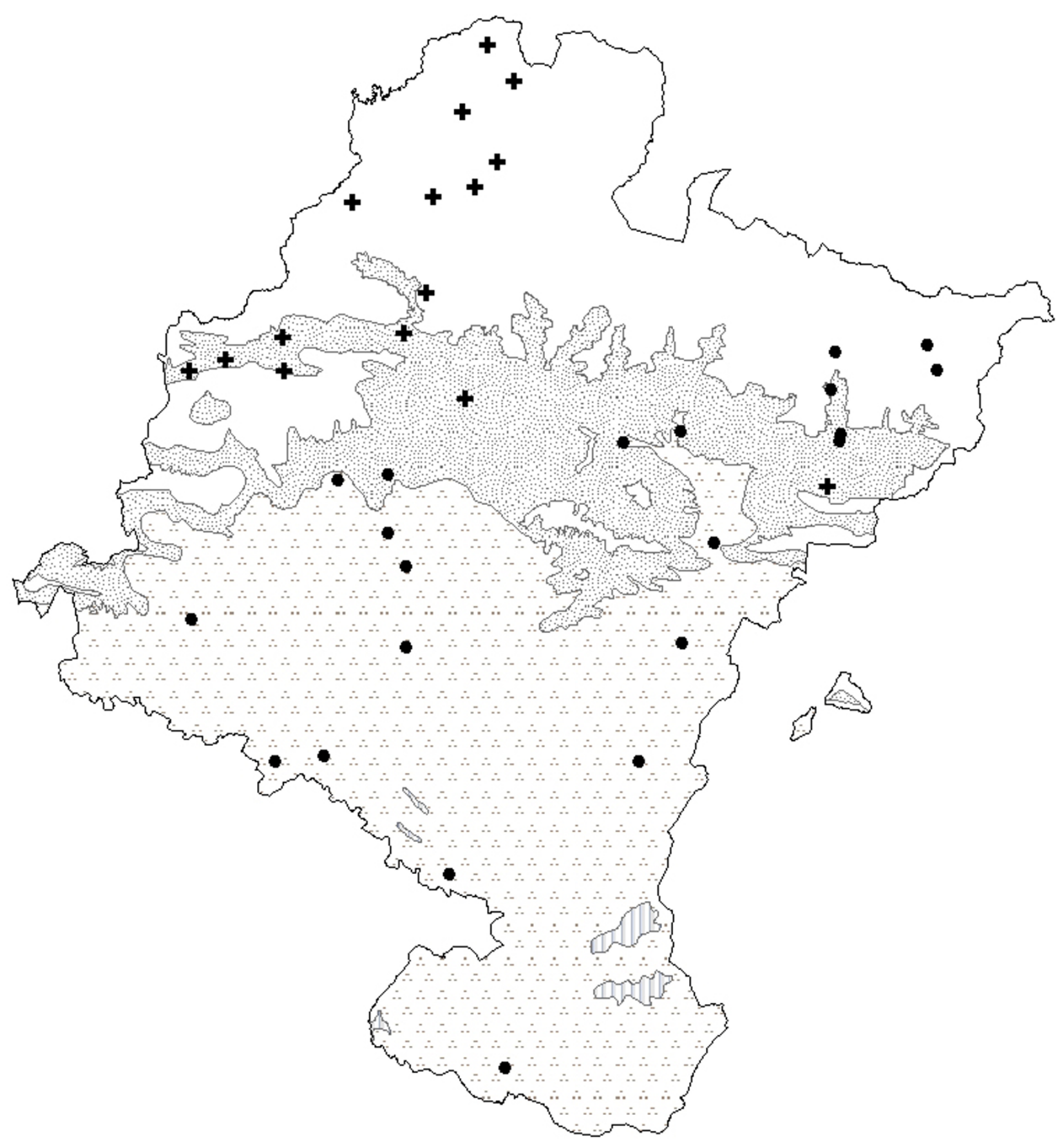

\section{Figure 8}

Map of the distribution of use of skin species (I) (except Allium cepa). + Anagallis arvensis and/or Anagallis foemina. Hylotelephium maximum or Hylotelephium telephium. Bioclimates. Blank area: Temperate oceanic. Random dotted area: Temperate oceanic sub-mediterranean. Aggregately dotted area: Mediterranean pluviseasonal. Striped area: Mediterranean xeric.

Skin disorders: cuts, whitlows and bixikos (infected spots):

The morphology of Hylotelephium leaves facilitate its use as a "band-aid" (Table 3): the epidermis of the fresh leaves is peeled and placed directly on the wound. This healing property was noted by John Gerard in 1597 [70]. This plant is cultivated and used for this purpose throughout most of Navarra (Fig. 8), except the linguistic Basque area, 


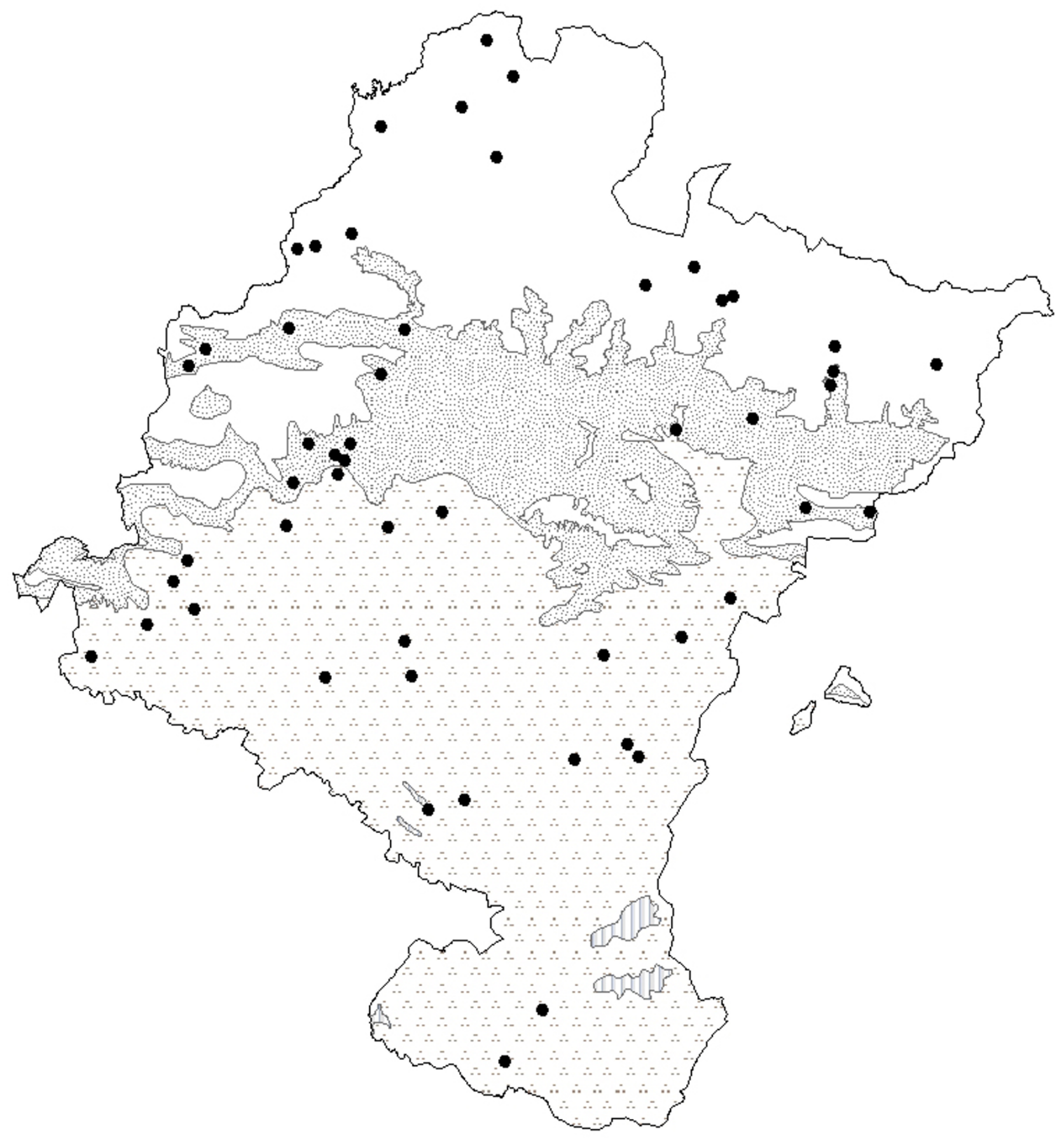

\section{Figure 9}

Map of the distribution of use of skin species (2). Allium cepa. Bioclimates. Blank area: Temperate oceanic. Random dotted area: Temperate oceanic sub-mediterranean. Aggregately dotted area: Mediterranean pluviseasonal. Striped area: Mediterranean xeric.

where it is substituted by the use of two wild species: Anagallis arvensis and A. foemina and called indifferently "pasmobelarra". Although those species appear to be ruderal throughout the territory of Navarra, without being affected by climate or substrate, the cultural factor determines the distribution of its use. This is a clear evidence 
that the dermatological use of Hylotelephium-Anagallis is a cultural substitution: use of Anagallis is reduced to the Basque area in Navarra, with its isolated houses where ancestral Basque traditions are still kept alive. Indeed, three people interviewed referred to those plants in the elaboration of ointments used by "pelotaris" (hand ball players) to cure wounds in the hand after matches. However, owing to its importance in Basque culture, it has been mentioned in several ethnography $[14,88]$ and botanic $[60,89]$ works on the region. Curiously, Hylotelephium maximum was cited three times in this reason for a non-dermatological application. Hyloteolephium is here known as "belarribelarra" (herb of the ear or eye), and the juice from its leaves is used to relieve the pain caused by cold to the ear. To continue with the plants that have dermatological applications, Allium cepa $\mathrm{L}$. is the most widely used species. Although it is allochthonous, it is part of the staple diet of all the houses and farm communities in Navarra, and is therefore always at hand. Its availability, which is favored by the underlying cultural factor which led to its cultivation, has been decisive in ensuring widespread use (Fig. 9). Moreover, the plant's medicinal antibacterial properties support the traditional application to which it is put [58].

\section{Conclusion}

-The results clearly show that ecological and cultural factors influence the choice and phytonymy of 18 medicinal plants in Navarra.

-Climate and substrate are the most important abiotic factors that determine a plant's availability and accessibility for medicinal use: if a plant is abundant, it is more likely to be used, and vice versa. Even in the case of Santolina chamaecyparissus subsp. squarrosa, the wide availability of this species as a result of environmental factors means that it is the most widely used chamomile in Navarra, over and above the cultural elements which brand it with a pejorative phytonym and relegate it to second position in areas where its use overlaps with that of Chamaemelum nobile and Helichrysum stoechas.

-Nonetheless, the cultural factor in Navarra is decisive when it comes to the medicinal use of plants, over and above their abundance and natural availability. The cultural background determines that plants are chosen for two reasons: 1) the local population have a sense of the chemical and medicinal properties of the plant, as in the case of Jasonia glutinosa and Chamaemelum nobile, where the cultural factor means that they are chosen even in areas outside their natural habitat, which means that their area of use is greater than their ecological distribution. This is obviously also the case with those allochthonous species which are grown in this region because of longstanding traditions or cultural influences which encour- age their use, be they generalized (Allium cepa, Hylotelephium, Olea europea) or more specific to a particular area (Bidens aurea, Tanacetum parthenium, Matricaria recutita); 2) beliefs or traditions of a particular culture, as in the case of Tanacetum parthenium, which is used to protect the houses in the Basque-speaking area. On the other hand, this research shows that in Navarra, cultural isolation or age-old cultural traditions are the crucial factor which keeps alive the use of particular species today (Sideritis hyssopifolia, Anagallis).

-The existence of numerous polysemies in Navarra have shown that one plant can replace another which is less widely available (as in the case of the chamomiles), and in many cases we were able to find out from the local names which plant was regarded as the substitute or second choice. When the use and name of two plants overlapped in one place, the plant which was considered inferior was given a pejorative name ("rough chamomile" in the case of Santolina chamaecyparissus y Anthemis arvensis, or "false tea" in the case of Jasonia tuberosa). However, this did not happen when two plants with different names were applied for the same purpose (as in the replacement Hylotelephium-Anagallis, which was clearly determined by cultural factors).

-On the other hand, the large number of species known as "chamomile" reveals a great demand for digestive medicinal plants. As the supply of the most valued ones was insufficient, less valuable species such as Anthemis arvensis or Tanacetum parthenium were used.

-Climate, substrate and culture have been shown to be useful for understanding synonymy, plant complexes or simple substitutions of plants, and we may conclude that they are very useful for discussing ethnopharmacological data.

\section{Acknowledgements}

We would like to express our sincerest gratitude to all the people who shared with us not only their knowledge about popular medicine, but also their time, dedication and affection. We would also like to thank the Gobierno de Navarra for the grant which made it possible to complete this Ph.D. dissertation, and the Fundación Universitaria de Navarra for financial support. We would also like to thank the reviewers of this article for their suggestions, which have helped us to improve it in many ways.

\section{References}

I. Prance GT: What is ethnobotany today? J Ethnopharmacol |99|, 32:209-216

2. Etkin NL, Elisabetsky E: Seeking a trasdisciplinary and culturally germane science: the future of ethnopharmacology. J Ethnopharmacol 2005, 100:23-26.

3. Soejarto DD, Fong HHS, Tan GT, Zhang HJ, Ma CY, Franzblau SG, Gyllenhaal C, Riley MC, Kadushin MR, Pezzuto JM, Xuan LT, Hiep NT, Hung NV, Vu BM, Loc PK, Dac LX, Binh LT, Chien NQ, Hai NV, Bich T-Q, Cuong NM, Southavong B, Sydara K, Bovamanivong S, Ly HM, Thuy TV, Rose WC, Dietzman GR: Ethnobotany/ethnopharma- 
cology and mass bioprospecting: Issues on intellectual property and benefit-sharing. J Ethnopharmacol 2005, 100:15-22.

4. Bonet MÀ: Estudi etnobotànic del Montseny. In PhD Thesis Faculty of Pharmacy, University of Barcelona; 200I.

5. Rigalt M: Estudis etnobotànics a la Vall de Camprodon (Alta VAll del Ter, Pirineus). In Master Degree Thesis Faculty of Farmacy, University of Barcelona; 2005.

6. Johns T, Kokwaro JO, Kimanani EK: Herbal remedies of the Luo of Siaya District, Kenya: establishing quantitative criteria for consensus. Econ Bot 1990, 44(3):369-381.

7. Akerreta S, López V, Calvo MI, Cavero RY: Plantas medicinales en la medicina tradicional de Navarra: primera aproximación. Revista de Fitoterapia 2006, I:65-69.

8. Gobierno de Navarra: Mapa geológico de Navarra. Pamplona: Gobierno de navarra; 1997.

9. López ML, Piñas S, Akerreta S, Amezketa A, López S: Mapa bioclimático-2 a aproximación-, mapa ombrotípico- $\left.\right|^{a}$ aproximación-y diversidad bioclimática de Navarra. Publicaciones de Biología de la Universidad de Navarra, Serie Botánica 2005, 16:87-97.

10. Martin J, Floristán A: Bardenas Reales de Navarra. Pamplona: Caja de Ahorros de Navarra; 1997.

II. Gil T, Berastegi A, Lorda M, Peralta J: Áreas importantes para las plantas vasculares en Navarra (N Península Ibérica). In 4th European conference about wild plant conservation: 17-20 September 2004; Valencia (Spain)

12. Loidi J, Báscones JC: Memoria y Mapa de series de vegetación de Navarra. Pamplona: Gobierno de Navarra; 1995.

13. Lorda M: Flora del Pirineo navarro. Leioa: Servicio Editorial de la Universidad del País Vasco; 2001.

14. Etniker: Euskalerria: Medicina popular en Vasconia. Bilbao: Eusko Jaurlaritza and Gobierno de Navarra; 2004.

15. Martin G]: Ethnobotany. A methods manual. London: Chapman \& Hall; 1995.

16. Castroviejo $S$, et al: Flora Ibérica. Plantas vasculares de la Península Ibérica e Islas Baleares. Volume I-VIII, X, XIV, XXI. Madrid: Real Jardín Botánico-CSIC; 1986.

17. Aizpuru I, Aseginolaza C, Uribe-Echevarría PM, Urrutia P, Zorrazkin I: Flora del País Vasco y territorios limítrofes. Bilbao: Gobierno Vasco; 2000.

18. Vallès ]: Los nombres populares de las plantas: método y objetivo en etnobotánica. Monograf Jard Bot Córdoba 1996, 3:7-14.

19. Lacoizqueta JM: Diccionario de los nombres euskaros de las plantas. Pamplona: Fundación Diario de Navarra; 2003.

20. Barriola IM: La Medicina Popular en el País Vasco. San Sebastián: Itxaropena 1952

21. Erkoreka A: Análisis de la Medicina Popular Vasca. Bilbao: Labayru Ikastegia; 1985.

22. Bonet $M \grave{A}$, Blanché $C$, Vallès J: Ethnobotanical study in river Tenes valley (Catalonia, Iberian Peninsula). J Ethnopharmacol 1992, 37:205-212.

23. Bonet MÀ, Parada M, Selga A, Vallès J: Studies on pharmaceutical ethnobotany in the regions of L'Alt Empordà and Les Guilleries (Catalonia, Iberian Peninsula). J Ethnopharmacol 1999, 68:145-168.

24. Bonet MÀ, Vallès J: Plantes, remeis i cultura popular de Montseny. In Etnobotànica d' una Reserva de la Biosfera Figueres: BRAU edicions; 2006

25. Agelet A, Vallès J: Studies on pharmaceutical ethnobotany in the region of Pallars (Pyrenees, Catalonia, Iberian Peninsula). Part I. General results and new or very rare medicinal plants. J Ethnopharmacol 200I, 77:57-70.

26. Agelet $A$, Vallès J: Studies on pharmaceutical ethnobotany in the region of Pallars (Pyrenees, Catalonia, Iberian Peninsula). Part II. New or very rare uses of previously known medicinal plants. J Ethnopharmacol 2003, 84:2I I-227.

27. Agelet $A$, Vallès J: Studies on pharmaceutical ethnobotany in the region of Pallars (Pyrenees, Catalonia, Iberian Peninsula). Part III. Medicinal uses of non-vascular plants. J Ethnopharmacol 2003, 84:229-234.

28. Fajardo J, Verde A, Rivera D, Obón C: Las plantas en la cultura popular de la provincia de Albacete. Albacete: Ediciones Instituto de Estudios Albacetenses; 2000.

29. González-Tejero MR, Molero-Mesa J, Casares-Porcel M, Martínez Lirola MJ: New contributions to the ethnopharmacology of Spain. J Ethnopharmacol 1995, 45:157-165.
30. Lastra J], Bachiller LI: Plantas medicinales en Asturias y la cornisa cantábrica. Gijón: Trea 1997.

31. Martínez MJ, González MR, Molero J: Ethnobotanical resources in the province of Almería, Spain: Campos de Níjar. Econ Bot 1996, 50:40-56

32. Vázquez FM, Suarez MA, Pérez A: Medicinal plants used in the Barros Area, Badajoz Province (Spain). J Ethnopharmacol 1996, 55:8I-85

33. Pardo de Santayana M, Blanco E, Morales R: Plants known as té in Spain: an ethno-pharmaco-botanical review. J Ethnopharmacol 2005, 98:I-19.

34. Villar L, Palacín JM, Calvo C, Gómez D, Montserrat G: Plantas Medicinales del Pirineo Aragonés y demás tierras oscenses. Huesca: C.S.I.C.-Diputación de Huesca 1992.

35. Tardío J, Pardo de Santayana M, Morales R: Ethnobotanical review of wild edible plants in Spain. Bot J Linn Soc 2006, I52:22-7I.

36. Parada $M$, Selaga $A$, Bonet MÀ, Vallès J: Etnobotànica de les terres gironines. Girona: Diputació de Girona 2002.

37. Raja $D$, Blanché $C$, Vallés J: Contribution to the knowledge of the pharmaceutical ethnobotany of La Segarra region (Catalonia, Iberian Peninsula). J Ethnopharmacol I997, 57:149-160.

38. Bonet MÀ, Vallès J: Use of non-crop food vascular plants in Montseny biosphere reserve (Catalonia, Iberian Peninsula). Int J Food Sci Nutr 2002, 53:225-248.

39. Pardo de Santayana M, Morales R: Consideraciones sobre el género Jasonia (Compositae, Inuleae). Sistemática y usos. Acta Botanica Malacitana 2004, 29:221-232.

40. Agelet $A$, Muntané J, Parada M, Vallès J: Plantes medicinals del Pirineu català. Sant Vicenç de Castellet: Farell 2002

4I. Guillén MD, Ibargoitia ML: Volatile components obtained from the leaves of Jasonia glutinosa. Food Chem 1996, 56:I55-I58.

42. Bermejo-Benito P, Abad MJ, Villaescusa L, González MA, Silván AM: Sesquiterpenes from Jasonia glutinosa : In Vitro Anti-inflamatory activity. Biol Pharm Bull 2002, 25: I-4.

43. Pamplona JD: Enciclopedia de las plantas medicinales. Madrid: Safeliz; 1997.

44. Gil Pinilla M: Estudio etnobotánico de la flora aromática y medicinal del término municipal de Cantalojas (Guadalajara). In PhD Thesis Universidad Complutense de Madrid; 1995.

45. Gobierno de Navarra: Catálogo florístico de Navarra. Pamplono I99I, I-III:

46. Pignatti S: Flora d'Italia. Volume II. Bologna: Edaglicole; 1992.

47. Ivancheva $S$, Stantcheva B: Ethnobotanical inventory of medicinal plants in Bulgaria. J Ethnopharmacol 2000, 69:165-172.

48. Hernández-Pérez M, Rabanal RM: Evaluation of the anti-inflamatory and analgesic activity of Sideritis canariensis var. pannosa in mice. J Ethnopharmacol 2002, $81: 43-47$.

49. Hernández-Pérez $M$, Sánchez-Mateo $C C$, Montalbetti-Moreno $Y$ Rabanal RM: Studies on the analgesic and anti-inflamatory effects of Sideritis candicans Ait. var. eriocephala Webb aerial part. I Ethnopharmacol 2004, 93:279-284.

50. What is mountain tee? [http://www.bergtee.de/eng/wasist bergtee.htm]

5I. Pieroni A, Muenz H, Akbulut M, Hüsnü K, Durmuçkahya D: Traditional phytotherapy and trans-cultural pharmacy among Turkish migrants living in Cologne, Germany. J Ethnopharmacol 2005, 102:69-88.

52. Torres F: Nombres y usos populares de las plantas silvestres en Almería. Almería: Diputación de Almería y Cajamar 2004.

53. Rodríguez Lyon ML, Díaz Lanza AM, Bernabé M, Villaescusa L: Flavone glysosides containing acetylated sugars from Sideritis hyssopifolia. Magn Reson Chem 2000, 38:684-687.

54. Tutin TG, Heywood VH, Burges NA, Moore DM, Valentine DH, Walters SM, Webb DA: Flora europaea. Volume IV. Cambridge: Cambridge University Press; 1976

55. Alarcón C, La Casa C, Motilva V, López A, Martin MJ: Ulcer-protecting effects of a flavonoid fraction from Bidens aurea. Role of endogenous prostaglandins and microvascular permeability. Phytomedicine 1997, 3:327-333.

56. WHO (World Health Organization): Monographs on selected medicinal plants. Geneva I999, I-II:

57. ESCOP: ESCOP Monographs: the scientific foundation for herbal medicinal products. Stuttgart: Thieme 2003.

58. Blumenthal M, Busse WR, Goldberg A, Gruenwald J, Hall T, Riggins CW, Rister RS: The complete German Comission E Monographs. American Botanical Council, Boston 1998. 
59. Muñoz-Centeno LM: Plantas medicinales españolas: Jasonia glutinosa (L.) DC. (Asteraceae) (Té de roca). Acta Botanica Malacitana 2003, 28:22I-227.

60. Fernández M: Las plantas en la medicina popular (I-Navarra húmeda del noroeste). Pamplona: Eusko lkaskuntza; I98I.

6I. García Bona LM: Navarra, plantas medicinales. Pamplona: Caja de Ahorros de Navarra; I98I.

62. Ladero M, Valle CJ, Santos MT, Ruiz T, Fernandez MI: Estudio botánico de las manzanillas españolas. Stvdia botanica 1985 4:179-196

63. Agelet $A$, Bonet MÀ, Vallès J: Homegardens and their roles as a main source of medicinal plants in mountain regions of CataIonia (Iberian Peninsula). Econ Bot 2000, 54(3):295-309.

64. Giner RM, Ríos JL: Santolina chamaecyparissus. Revista de Fitoterapia. 2000, I:27-34.

65. Rivera D, Obón C: The ethnopharmacology of Madeira and Porto islands, a review. J Ethnopharmacol 1995, 46:73-93.

66. Blanco E, Macía MJ, Morales R: Medicinal and veterinary plants of El Caurel (Galicia, northwest Spain). J Ethnopharmacol 1999, 65: $113-124$

67. Camejo-Rodrigues J, Ascensâo L, Bonet MÀ, Vallès J: An ethnobotanical study of medicinal and aromatic plants in the Natura Park of "Serra de Sâo Mamede" (Portugal). J Ethnopharmacol 2003, 89:199-209.

68. Novais MH, Santos I, Mendes S, Pinto-Gomes C: Studies on pharmaceutical ethnobotany in Arrabida Natural Park (Portugal). J Ethnopharmacol 2004, 93: 183-195.

69. Tardío J, Pascual H, Morales R: Wild food plants traditionally used in the province of Madrid, Central Spain. Econ Bot 2005 , 59:122-136.

70. Crellin JK, Philpott J: Herbal Medicine. Past and Present. A reference guide to medicinal plants. Volume II. Durhan and London: Duke University Press; 1990.

7I. Carnat A, Carnat AP, Fraisse D, Ricoux L, Lamaison JL: The aromatic and polyphenolic composition of Roman camomile tea. Fitoterapia 2004, 75:32-38.

72. Carini M, Aldini G, Furlanetto S, Stefani R, Facino RM: LC coupled to ion-trap MS for the rapid screening and detection of polyphenol antioxidants from Helichrysum stoechas. J Pharm Biomed Anal 200I, 24:517-526.

73. Plants for a future [http://www.comp.leeds.ac.uk/pfaf]

74. Abella I: La magia de las plantas. Barcelona: Integral 2003.

75. Jain NK, Kulkarni SK: Anticonceptive and anti-inflammatory effects of Tanacetum parthenium $L$. extract in mice and rats. Ethnopharmacol 1999, 68:25I-259.

76. Williams CA, Harbone JB, Geiger H, Hoult JRS: The flavonoids of Tanacetum parthenium and T. vulgare and their anti-inflamatory properties. Phytochemistry 1999, 5 I :417-423.

77. Gurib-Fakim A: Medicinal plants: traditions of yesterday and drugs for tomorrow. Mol Aspects Med 2006, 27: I-93.

78. Wu C, Chen F, Wang X, Kim H, He G, Haley-Zitlin V, Huang G: Antioxidant constituents in feverfew (Tanacetum parthenium) extract and their chromatographic quantification. Food Chem 2006, 96:220-227.

79. Bonet MÀ, Vallès J: Pharmaceutical ethnobotany in the Montseny biosphere reserve (Catalonia, Iberian Peninsula). General results and new or rarely reported medicinal plants. J Pharm Pharmacol 2003, 55:259-270.

80. Stübing G, Peris JB: Plantas medicinales de la Comunidad Valenciana. Generalitat Valenciana, Consellería de Medio Ambiente, D.L., Valencia 1998.

8I. Duke JA: Handbook of medicinal herbs. New York: CRC Press; 1986.

82. Trease GE, Evans WC: Tratado de Farmacognosia. México: Interamericana; 1986.

83. British Herbal Medicine Association: British Herbal Compendium. A handbook of scientific information on widely used plant drugs. Bournemouth 1992.

84. Ross IA: Medicinal plants of the world: chemical constituents, traditional and modern medicinal uses. Totowa: Humana Press; 2003.

85. Chudnicka A, Matysik G: Research of enzymatic activities of fresh juice and water infusions from dry herbs. J Ethnopharmacol 2005, 99:28I-286.

86. Somova LI, Shode FO, Ramnanan P, Nadar A: Antihypertensive, antiatherosclerotic and antioxidant activity of triterpenoids isolated from Olea europaea, subspecies africana leaves. Ethnopharmacol 2003, 84:299-305.

87. Linares $E$, Robert A, Bye JR: A study of four medicinal plant complexes of Mexico and adjacent united status. J Ethnopharmacol 1987, 19:153-183.

88. Garmendia J: Rito y fórmula en la medicina popular vasca. La salud por las plantas medicinales. San Sebastián: Txertoa 1990.

89. Vázquez-Molina G: Plantas medicinales en el País Vasco. San Sebastián: Txertoa 1991.
Publish with Bio Med Central and every scientist can read your work free of charge

"BioMed Central will be the most significant development for disseminating the results of biomedical research in our lifetime. "

Sir Paul Nurse, Cancer Research UK

Your research papers will be:

- available free of charge to the entire biomedical community

- peer reviewed and published immediately upon acceptance

- cited in PubMed and archived on PubMed Central

- yours - you keep the copyright
BioMedcentral 